\title{
PERENCANAAN PENJADWALAN TENAGA KERJA PADA UKM SONGKOK IKAT KEPALA
}

\author{
Welly Bachtria Nugroho \\ Department of Management FEB UMM \\ E-mail: bachtriawelly@gmail.com
}

\begin{abstract}
Songkok Ikat Kepala was one of UKM which produce songkok in Gresik. This UKM Songkok Ikat Kepala was produced by strategy "make to order" and there was no guideline for period production. Problems that occurred were known asdelayed production process at the process of sewing. The aim of this study was (1) to analyze the planning of labor scheduling and (2) to determine the standard of estimation of item production process. The data were analyzed by using period study and gantt diagram techniques. The results of the study showed that there were 2 standards of estimation, those are fast and low standards. Fast standard needed the work estimation in 444 seconds. However, low standard needed the work estimation in 536 seconds. Therefore, this study was expected to be guidance to arrange the schedule by using gantt diagram.
\end{abstract}

Keywords : scheduling, period study, gantt diagram

\section{PENDAHULUAN}

Suatu produksi merupakan hal yang penting dan inti di dalam perusahaan. Ketika perusahaan melakukan produksi tentunya memiliki waktu pengerjaan tugas yang dibuat untuk tenaga kerja agar pada proses produksi tersebut berjalan dengan baik. Proses menyangkut tahap awal dalam perusahaan dikarenakan proses produksi merupakan hal yang begitu penting dan dengan adanya perencanaan waktu yang baik, sehingga bisa menforsir waktu yang ditempuh pada saat pembuatan produk itu lebih efisien.

Sumber daya manusia merupakan faktor penentu dalam perusahaan dalam meningkatkan produksi.Hal tersebut harus diakui karena perkembangan dunia sekarang ini adalah hasil dari pemikiran manusia untuk mampu memenuhi keinginan dan kebutuhan hidup manusia itu sendiri.Hal tersebut berhubungan dengan kemampuan perusahaan-perusahaan untuk mengikuti laju perkembangan dan kepekaan terhadap perubahan yang terjadi di dunia bisnis.

Industri UKM merupakan unit usaha kecil menengah, rata-rata UKM di Indonesia merupakan unit usaha yang modalnya dari perorangan sendiri dan ada yang merupakan unit usaha binaan dan bantuan modal dari pemerintah daerah berdasarkan usaha yang sekiranya mampu bersaing di pasar yang lebih luas jangkauannya. Unit usaha pembuatan songkok semakin 
berkembang dikarenakan mayoritas penduduk di Indonesia banyak yang menganut agama Islam.Jadi pelaku usaha sangat banyak yang mendirikan UKM di bidang peralatan ibadah dan salah satunya adalah produk songkok.

Songkok Ikat Kepala yang berbasis di kota Gresik ini salah satu perusahaan yang bergerak pada usaha kecil menengah dimana keadaan intern perusahaan, seperti potensi tenaga kerja yang masih belum optimal, masih adanya tenaga kerja yang mengalami permasalahan keterlambatan pada proses pengerjaan pembuatan songkok.
Masih belum adanya standar waktudi perusahaan, maka permasalahan yang terjadi harus di hitung waktu standar pengerjaannya dan dijadwalkan tenaga kerja yang matang, agar produktivitas tenaga kerja yang ada dapat ditingkatkan.

Hal ini dapat diwujudkan melalui adanya penyesuaian seperti adanya standar waktu yang dijadikan patokan dalam menyelesaikan tugas yang berguna untuk meningkatkan produksi pada perusahaan.Sehingga setiap tenaga kerja dapat menghasilkan jumlah produksi yang meningkat.Data keterlambatan bisa dilihat sebagai berikut :

Tabel 1. Data keterlambatan

\begin{tabular}{lrccc}
\hline \multirow{2}{*}{ Tanggal Pemesanan } & Jumlah & \multicolumn{2}{c}{ Deadline } & \multirow{2}{*}{ Tanggal Selesai } \\
\cline { 3 - 4 } & pesanan & Pemesan & Pembuatan & \\
\hline 14 Januari 2017 & 2200 unit & 26 Januari 2017 & 16 Januari 2017 & 28 Januari 2017 \\
9 Februari 2017 & 2300 unit & 23 Februari 2017 & 11 Februari 2017 & 25 Februari 2017 \\
20 Maret 2017 & 2350 unit & 31 Maret 2017 & 21 Maret 2017 & 3 April 2017 \\
\hline
\end{tabular}

Tujuan dari penelitian ini adalah untuk mengetahui standar waktu yang dibutuhkan dalam proses produksi pembuatan songkok pada UKM Songkok Ikat Kepala dan untuk mendiskripsikan penjadwalan tenaga kerja pada UKM Songkok Ikat Kepala

\section{TINJAUAN PUSTAKA}

Seperti pada penelitian yang dilakukan oleh Noni Tri Rahmawati (2015). Penelitian tersebut memiliki tujuan untuk mengetahui pengukuran kerja pada divisi pompa minyak PT Bukaka Teknik Utama Tbk. Hasil data yang diperoleh meningkat dengan jumlah unit yang semula dihasilkan 2500 perbulan pada setiap produk, produk Roller Step dibagian pemotonganmeningkat sebesar 83 unit, dibagian finishing meningkat sebesar 53 unit, dibagian fininshing meningkat sebesar 1.219 unit. Produk Roda Fork Lift dibagian pemotongan meningkat jumlah produknya sebesar 63 , dan dibagian finishing meningkat sebesar 532 unit. Selanjutnya penelitian yang dilakukan oleh Noriah Yusoff, Ahmed Jaffar, Norliana Mohd Abbas dan Nor Hayati Saad (2012) dengan topik pengukuran kinerja untuk perbaikan proses pada perusahaan manufaktur kursi mobil. Dengan menggunakan teknik metode studi waktu sebagai upaya membangun waktu patokan dalam pembuatan kursi mobil. Dan hasilnya diketahui 13,42 menit waktu siklus untuk efisiensi produksi $100 \%$ dan 14,09 menit waktu siklus untuk efisiensi produksi $95 \%$ yang dapat digunakan sebagai waktu standar pembuatan. 
Lalu penelitian yang dilakukan oleh Dyah Ika Rinawati, Diana Puspitasari dan Fatrin Muljadi (2012)memiliki topik tentang penentuan waktu standar dan jumlah tenaga kerja optimal yang dilakukan pada perusahaan batik cap IKM Batik Saud Effendy. Penelitian ini menggunakan metode Studi waktu. Hasilnya yaitu waktu baku pengerjaan 1 lot batik cap adalah 36 jam 30 menit 36 detik. Jumlah tenaga kerja usulan untuk untuk untuk proses pemotongan kain mori 1 orang, pengecapan 5 orang, pewarnaan 1 orang, pengeringan dan pencucian 1 orang, penglorodan 1 orang, pengeringan 1 orang, dan packing 1 orang.

Penelitian yang keempat dilakukan oleh Subhan, M. Thaib Hasan, Suhendra (2015) yakni peningkatan produktivitas kerja pada industri batu bata. Penelitian ini menggunakan teknik analisis studi waktu dan work sampling dengan hasil yang didapat adalah waktu standar operator dalam menyelesaikan pekerjaanya sebesar 2,082 menit dari hasil pengolahan data yang telah dilakukan diperoleh bahwa, jumlah tenaga kerja yang dibutuhkan pada bagian percetakan batu bata sebesar 7 orang sedangkan jumlah tenaga kerja yang tersedia sebanyak 3 orang dan presentase produktivitas rata-rata seluruh operator adalah sebesar $95.04 \%$.

Penelitian yang terakhir dilakukan oleh Pardeep Kumar dan Mukesh Kumar (2015) dengan tema penjadwalan produksi dengan pertimbangan waktu pengangkutan dan pengolahan waktu kriteria terpendek. Penelitian ini menggunakan metode Job Shop dan
Gantt Chart yang dimana hasilnya pada studi kasus pertama dengan ukuran 4x6 memiliki makespan 329 dan dengan usulan total makespan 340dan pada studi kasus kedua dengan ukuran $5 \times 5$ memiliki makespan 34 dengan usulan total makespan 47.

Pengukuran kerjaadalahsuatu aktivitas untuk menentukan waktu yang dibutuhkan oleh seseorang operator dalam melaksanakan kegiatan kerja dalam kondisi dan tempo kerja yang normal(Heizer \& Render, 2005).Pengukuran kerja berguna untuk menentukan waktu yang dibutuhkan dalam melaksanaka masing-masing pekerjaan secara berurutan, selain itu pengukuran kerja sendiri mengamati secara langsung waktu kerja yang dibutuhkan oleh seorang operator apakah sudah sesuai dengan waktu yang diberikan oleh perusahan atau masih mengalami ketidaksesuaian

Salah satu metode pengukuran kerja adalah studi waktu, studi waktu merupakan teknik yang melibatkan sampel kinerja dari seorang pekerja yang digunakan untuk menetapkan suatu standar di perusahaan. Dimana studi ini menggunakan stopwatch sebagai alat bantu dalam penghitungan waktu dari proses produksi yang ada di perusahaan (Heizer \& Render, 2015).

Penjadwalan adalah suatu tahapan dari pengawasan produksi yang menetapkan pekerjaan dalam urut-urutan yang sesuai dengan prioritasnya dan kemudian dilengkapi pelaksanaan rencana tersebut pada waktu yang tepat dengan urutan yang benar, sehingga berhubungan dengan kapan suatu pekerjaan akan dilaksanakan pada 
suatu bagian produksi(Assauri, 2008).

Diagram Gantt menampilkan beban kerja relatif di dalam sistem sehingga para manajer bisa tahu penyesuaian seperti apa yang tepat untuk dilakukan dalam lantai produksi. Diagram perencanaan yang digunakan untuk menjadwalkan sumber daya dan mengalokasikan waktu. Ketika digunakan dalam pembebanan diagram gantt menujukkan pembebanan dan waktu luang pada beberapa departemen, mesin atau fasilitas (Heizer \& Render, 2010). Kerangka pikir pada penelitian ini akan dipaparkan oleh Gambar 1 sebagai berikut:

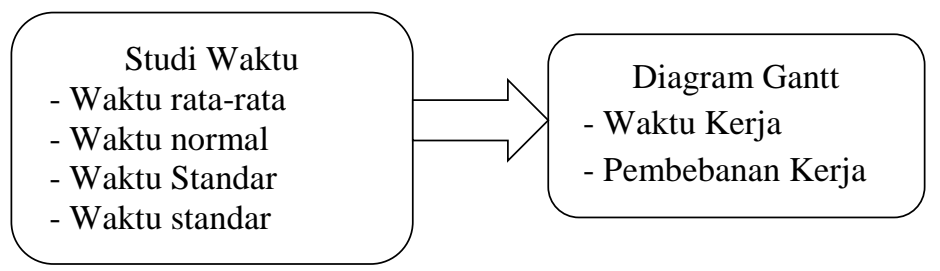

Gambar 1. Kerangka Pikir Penelitian

\section{METODE PENELITIAN}

Penelitian ini dilakukan perusahaan songkok pada UKM Songkok Ikat Kepala, yang terletak di Jl. KH Kholil gang 10 No. 12 Kabupaten Gresik. Penelitian ini menggunakan jenis penelitian aplikasi model. Jenis penelitian ini bertujuan untuk menerapkan, menguji, mengevaluasi masalahmasalah praktis. Definisi operasional variabel adalah penjelasan mengenai cara-cara tertentu yang diperlukan oleh peneliti untuk mengukur construct menjadi variabel peneliti yang dapat diuji.

Variabel dalam penelitian ini yang pertama adalah waktu rata-rata, yaitu waktu siklus pekerjaan yang telah diobservasi pada setiap proses produksi. Dengan Jumlah waktu yang diterima untuk masing-masing elemen dibagi dengan jumlah observasi pada UKM Songkok Ikat Kepala.Satuan yang digunakan detik. Variabel kedua adalah waktu normal. Waktu yang digunakan sebagai acuan dalam proses produksi. Dengan rata-rata waktu yang diobservasipada UKM Songkok Ikat Kepala dan dikalikan pemeringkatan kinerja. Satuan yang digunakan satuan detik. Pemeringkatan kinerja sendiri terbagi dengan 2 interval yakni tinggi dan rendah, dikarenakan ada pengerjaan yang cepat dan lambat sehingga ada 2 interval tersebut.

Variabel ketiga adalah waktu standar yaitu waktu kerja masingmasing yang sesungguhnya. Jadi, total waktu normal dibagi dengan 1 dikurangi faktor cadangan. Faktor cadangan ini diambil dari faktorfaktor yang ada di UKM Songkok Ikat Kepala seperti cadangan pribadi, cadangan membungkuk dancadangan pencahayaan kurang.Satuan yang digunakan detik. Selanjutnya adalah waktu kerja yakni banyaknya waktu hari kerja yang akan dijadwalkan pada proses pembuatan songkok pada UKM Songkok Ikat Kepala.

Yang terakhir adalah pembebanan kerja. Terdapat 2 interval yaitu tinggi dan rendah maka di tabel diagram gantt terdapat 2 interval tersebut dalam 
mencantumkan tabel penjadwalan. Pembebanan kerja ini berupa waktu dimulainya tugas sampai dengan penyelesaian tugas, yang dimana diberikan rentang diagram batang alur waktu pengerjaan tugas.

Populasi yang digunakan dalam penelitian ini adalah seluruh proses produksi 8 aktivitas pada pembuatan songkok di UKM songkok Ikat Kepala dengan total 280 kali pengamatan.Sampel dalam penelitian ini menggunakan teknik purposive sampling. Sampel yang digunakan proses poduksi penjahitan mesin dengan 3 aktivitas yang mengalami keterlambatan dengan jumlah 120 kali pengamatan. Sumber data yang digunakan yaitu data primer dan data sekunder. Alat analisis yang digunakan adalah studi waktu dan diagram gantt.

Studi waktu adalah teknik yang melibatkan sampel kinerja pekerja dan menggunakannya untuk menetapkan suatu standar. Untuk menentukan standar dengan mengikuti delapan langkah berikut (Heizer dan Render, 2015) yaitu (1) mendefinisikan tugas untuk dipelajari, (2) membagi tugas kedalam elemen secara persis tepat, (3) membagi berapa banyak kali untuk mengukur tugas, (4) waktu dan mencatat waktu mendasar dan memeringkatkan kinerja, menghitung rata-rata waktu yang diobservasi (aktual) dengan menggunakan rumus berikut :

Rata-rata waktu yang diobservasi $=$ Jumlah waktu yang diterima untuk kinerja masing-masing e lemen Jumlah observasi

(6) menentukan pemeringkatan kinerja (kecepatan kerja) dan kemudian menghitung waktu normal untuk masing-masing elemen dengan rumus:

$$
\begin{gathered}
\text { Waktu Normal = Rata-rata waktu } \\
\text { diobservasi x Faktor } \\
\text { pemeringkatan kinerja }
\end{gathered}
$$

(7) menambahkan waktu normal untuk tiap elemen dalam mengembangkan total waktu normal bagi tugas, (8) menghitung waktu standar dengan rumus:

Waktu standar $=\frac{\text { Total } \text { waktu normal }}{1-\text { Faktor } \text { cadangan }}$

Teknik analisis data menggunakan diagram Gantt Chart, merupakan diagram perencanaan yang digunakan untuk penjadwalan sumber daya dan alokasi waktu (Heizer \& Render, 2010). Terdapat 3 langkah dalam membuat diagram Gantt Chart yang akan dijelaskan sebagai berikut : pertama, mengidentifikasikan waktu yang diperlukan dalam menyelesaikan suatu tugas, kedua menggambarkan sumbu horizontal waktu pelaksanaannya dan menuliskan tugas yang akan dikerjakan berdasarkan urutan waktu bagian atas, dan ketiga menggambarkan Diagram Batang (Bar Graph) untuk menunjukkan awal mulai pengerjaan tugas serta rentang waktu yang diperlukan untuk melakukan tugas yang bersangkutan.

\section{HASIL PENELITIAN DAN PEMBAHASAN}

Tenaga Kerja yang ada di UKM songkok Ikat kepala memiliki kecepatan bekerja yang berbedabeda. Maka dari itu diperlukan adanya penentuan waktu guna 
memaksimalkan, menyeimbangkan proses produksi yang berjalan. Tahap awal perhitungan yakni menentukan dan menghitung standar waktu dalam proses produksi yang ada di UKM Songkok Ikat Kepala dengan menggunakan studi waktu. Studi waktu dapat dilakukan dengan mengikuti delapan langkah berikut ini, (1) mempelajari tugas apa saja yang akan diteliti atau dilakukan pengamatan pada proses produksi yang dilakukan pada perusahaan (pembuatan sketsa rangka, pemotongan, menjahit mesin jahit, menjahit manual finishing, pengemasan), (2) elemen pekerjaan yang ada diperjelas menjadi beberapa elemen-elemen pekerjaan dengan tepat dan sesuai yang ada pada perusahaan. Pada langkah ini didapatkan informasinya dari kepala produksi dan tenaga kerja yang ada di perusahaan. Dan dilakukan penelitian dengan menggunakan stopwatch.

Pembuatan sketsa rangka dilakukan dengan mensketsa kain, kertas dan kertas keras sesuai pola dan ukuran songkok yang akan dibuat. Selanjutnya memotong kain, kertas dan kertas keras sesuai dengan pola dan ukuran. Selanjutnya menjahit kerangka atas dan samping bagian dalam songkok serta menjahit beludru kerangka atas bagian dalam songkok, serta menjahit beludru sisi lingkar bagian kerangka luar songkok dan jahit finishing. Proses pengemasan dilakukan dengan melakukan pengecekan sisa benang dan menyikat bagian beludru songkok, serta melakukan pengemasan.

Bagian (3) terkait banyaknya jumlah percobaan untuk mengukur tugas yang ada pada perusahaan. Pada penelitian ini dalam melakukan pengamatan data sebanyak 10 kali dalam 1 elemen proses produksi untuk pembuatan songkok dan dibagi dengan 2 waktu yang berbeda yakni 5 kali pada pukul 08:00 WIB dan 5 kali pada pukul 13:00 WIB. terdapat 2 waktu yang berbeda pada pengamatan dikarenakan adanya tingkat faktor kelelahan pekerja dengan pengerjaan pada pagi hari dan siang hari. sampel yang diambil 3 aktivitas yang mengalami keterlambatan dengan 4 tenaga kerja untuk menghitung waktu standar.

Bagian (4) dengan rata-rata waktu yang telah diamati sebanyak 10 kali, terbagi atas 5 kali pengamatan pukul 08.00 WIB dan 5 kali pengamatan pukul 13.00 WIB dengan cara menjumlahkan setiap elemen pekerjaan dan membaginya untuk memperoleh hasil waktu ratarata.nRata-rata dari masing-masing proses penjahitan (mesin) dengan rumus:

Rata-rata waktu yang diobservasi = Jumlah waktu yang diterima untuk kinerja masing-masing elemen Jumlah observasi 
Tabel 2. Hasil Rata-rata Waktu Proses Yang Mengalami Keterlambatan setiap elemen pekerjaan (Penjahitan Mesin)

\begin{tabular}{llcccc}
\hline No & \multicolumn{1}{c}{ Aktivitas } & $\begin{array}{c}\text { Total } \\
\text { Waktu }\end{array}$ & $\begin{array}{c}\text { Jumlah } \\
\text { Observasi }\end{array}$ & Rata-Rata & $\begin{array}{c}\text { Kelompok } \\
\text { Cepat }\end{array}$ \\
\hline 1. & $\begin{array}{l}\text { Menjahit kerangka atas dan } \\
\text { samping bagian dalam } \\
\text { songkok }\end{array}$ & 5415 & 40 & 135 detik & 122 detik \\
2. $\begin{array}{l}\text { Menjahit bludru kerangka atas } \\
\text { bagian dalam songkok }\end{array}$ & 4222 & 40 & 105 detik & 92 detik \\
3. & $\begin{array}{l}\text { Menjahit Bludru sisi lingkar } \\
\text { bagian kerangka luar songkok }\end{array}$ & 8231 & 40 & 206 detik & 192 detik \\
\hline
\end{tabular}

Bagian (5) Pemeringkatan kinerja (kecepatan kerja) dan kemudian menghitung waktu normal untuk masing-masing elemen. Pada langkah keenam ini menentukan kecepatan kerja atau tingkat kinerja yang dimana untuk menormalkan waktu pengerjaan produksi yang ada pada perusahaan berbeda-beda ada yang cepat dan ada pula yang lambat. Maka ditentukan dengan cara hasil dari perhitungan rata-rata setiap elemen pekerjaan dibagi dengan ratarata waktu dikali100\%.

Memeringkatan kerja dan waktu normal proses yang mengalami keterlambatan terdapat 3 elemen atau aktivitas pada penjahitan mesin. Yang dimana setiap elemen pekerjaan ada 2 hasil yaitu cepat dan lambat. Karena di perusahaan terdapat karyawan yang cepat dalam menyelesaikan proses produksi dan ada yang terlambat.

Tabel 3. Hasil Pemeringkatan Kerja Proses yang mengalami keterlambatan

(Penjahitan mesin)

\begin{tabular}{clcc}
\hline No. & \multicolumn{1}{c}{ Elemen Kerja } & Kerja Cepat & Kerja Lambat \\
\hline 1 & $\begin{array}{l}\text { Menjahit kerangka atas dan samping } \\
\text { bagian dalam songkok }\end{array}$ & $90 \%$ & $112 \%$ \\
2 & $\begin{array}{l}\text { Menjahit bludru kerangka atas bagian } \\
\text { dalam songkok }\end{array}$ & $88 \%$ & $113 \%$ \\
3 & $\begin{array}{l}\text { Menjahit bludru sisi lingkar bagian } \\
\text { kerangka luar songkok }\end{array}$ & $93 \%$ & $106 \%$ \\
\hline
\end{tabular}

Bagian (6) waktu normal penjahitan dapat dihitung dengan rumus sebagai berikut:
Rata-rata waktu diobservasi dikali dengan faktor pemeringkatan kinerja

Tabel 4. Hasil Waktu Normal Proses yang mengalami keterlambatan (Penjahitan Mesin)

\begin{tabular}{cccc}
\hline No & Elemen Kerja & Kelompok Cepat & Kelompok Lambat \\
\hline 1 & $\begin{array}{c}\text { Menjahit kerangka atas dan samping } \\
\text { bagian dalam songkok }\end{array}$ & 121 detik & 151 detik \\
2 & $\begin{array}{c}\text { Menjahit bludru kerangka atas bagian } \\
\text { dalam songkok }\end{array}$ & 92 detik & 119 detik \\
3 & $\begin{array}{c}\text { Menjahit bludru sisi lingkar bagian } \\
\text { kerangka luar songkok }\end{array}$ & 191 detik & 218 detik \\
\hline
\end{tabular}


Bagian (7) jumlah waktu normal penjahitan (mesin) : Total waktu normal Cepat: $121+92+191=404$ detik, Total waktu normal Lambat : $151+119+218=488$ detik

Bagian (8) waktu standar yang diperlukan dengan cara total waktu normal yang terbagi oleh 2 interval waktu normal cepat dan waktu normal lambat dibagi dengan 1faktor cadangan. Faktor cadangan dihitung dengan cara menjumlahkan setiap unsur pada sampel penilitian yang terjadi selama pengamatan berlangsung. Pada penelitian ini faktor cadangan yang terjadi berbentuk presentase dimana pada pengamatan sebesar 9\% yang meliputi cadangan pribadi, cadangan membungkuk, cadangan pencahayan yang kurang dengan rumus:

$$
\text { Waktu standar := } \frac{\text { Total waktu normal }}{1-\text { Faktor cadangan }}
$$

Yang mana faktor cadangan $=9 \%$, cadangan membungkuk $=2 \%$ serta cadangan pencahayaan kurang $=2 \%$. Waktu proses tenaga kerja cepat penjahitan mesin adalah Cepat $=\frac{404}{1-9 \%}=443,95=444$ detik Waktu proses tenaga kerja lambat penjahitan mesin adalah :

Lambat $=\frac{488}{1-9 \%}=536,26=536$ detik Rata-rata waktu cepat dan lambat adalah:

$$
\text { Rata }- \text { rata }=\frac{444+536}{2}=490 \text { detik }
$$

Berdasarkan perhitungan waktu standar diketahui ada 2 yaitu standar waktu pengerjaannya cepar dan lambat pada proses yang mengalami permasalahan pada proses penjahitan mesin. Standar waktu cepat dapat dihasilkan 444 detik, standar waktu lambat dapat dihasilakan 536 detik dan rata-rata waktu yang cepat dan lambat dihasilkan 490 detik.

\begin{tabular}{|c|c|c|c|c|c|c|c|}
\hline \multirow[b]{2}{*}{ No } & \multicolumn{2}{|c|}{ Tenaga Kerja } & \multicolumn{2}{|c|}{ Beban pekerjaan } & \multicolumn{2}{|c|}{ Beban perusahaan } & \multirow{2}{*}{$\begin{array}{c}\text { Waktu } \\
\text { Penyelesaian }\end{array}$} \\
\hline & & & Perhari & $\begin{array}{l}\text { Per bulan } \\
\text { (26) }\end{array}$ & perhari & $\begin{array}{c}\text { Per bulan } \\
(26)\end{array}$ & \\
\hline \multirow[t]{2}{*}{1.} & T.K Cepat & $\mathrm{Fr}$ & 49 unit & 1274 unit & 45 unit & 1170 unit & 24 hari \\
\hline & & $\mathrm{Bt}$ & 49 unit & 1274 unit & 45 unit & 1170 unit & 24 hari \\
\hline \multirow[t]{2}{*}{2.} & T.K Lambat & Ud & 40 unit & 1040 unit & 45 unit & 1170 unit & 29 hari \\
\hline & & An & 40 unit & 1040 unit & 45 unit & 1170 unit & 29 hari \\
\hline
\end{tabular}

Tabel 5 Pembebanan Pekerjaan Tenaga Kerja Cepat dan Lambat

Tabel 5 menjelaskan tentang bagaimana setiap harinya perusahaan memberikan patokan jam kerja dari pukul 08.00 samai 15.00 dengan jam istirahat pukul 12.00 sampai 13.00 jadi total waktu pengerjaan ada 6 jam atau 21.600 detik. Sehingga pada tabel pembebanan pekerjaan dengan hasilnya tenaga kerja ada yang cepat dan lambat. Berikut sajian penjadwalan jangka pendek pada gambar diagram gantt dibawah ini: 


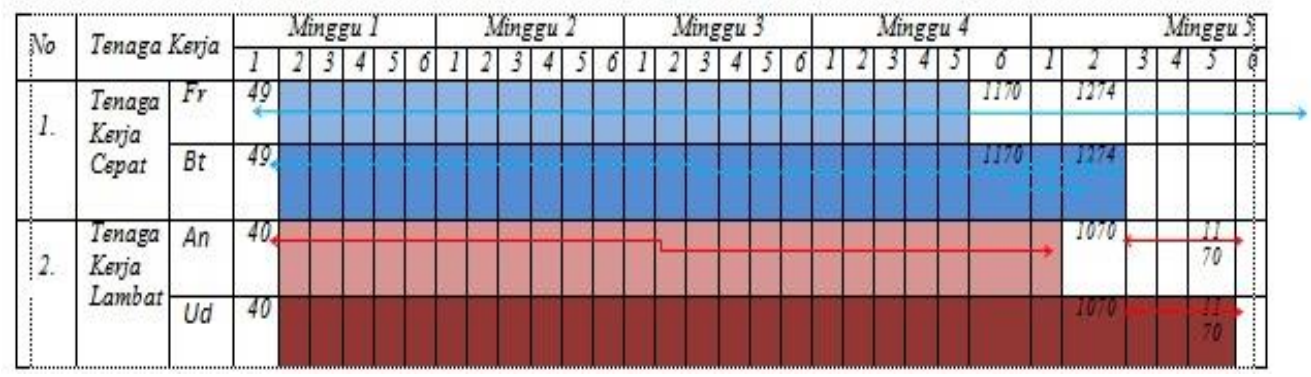

Gambar 2. Diagram Gantt Pembebanan Pekerja

Jadi hasil yang diketahui waktu standar untuk tenaga kerja cepat penjahitan mesin ada 2 orang Fr dan Bt dengan waktu sebesar 444 detik dapat menghasilkan 49 unit satu harinya, untuk 1 bulannya (26 hari) 1274 unit dan waktu standar untuk tenaga kerja lambat penjahitan mesin ada 2 orang Ud dan An sebesar 536 detik dapat menghasilkan 40 unit untuk satu harinya dan untuk perbulannya (26 hari) 1040 unit.

Sedangkan normalnya setiap tenaga kerja diberi beban 45 unit per hari atau 1170 unit per bulan (26 hari) dengan jumlah total 4680 unit per bulan. Sehingga tenaga kerja cepat dapat menyelesaikan 1170 unit dalam kurun waktu 24 hari dan 29 hari untuk tenaga kerja lambat. Dalam penelitian ini diagram Gantt berfungsi sebagai tabel yang menunjukkan jumlah waktu pekerjaan yang harus diselesaikan setiap tenaga kerja penjahitan mesin dalam memenuhi tugas yang diberikan.

Permasalahan yang terjadi pada UKM Songkok Ikat Kepala adalah adanya keterlambatan pada tahapan proses produksi. Mengakibatkan jalannya proses produksi songkok mengalami permasalahan serta tidak selesai sesuai dengan waktu yang telah ditentukan, tentunya itu akan membuat kerugian tersendiri bagi perusahaan. Dikhawatirkan akan mempengaruhi tingkat kepuasan pelanggan yang telah memesan produk di UKM Songkok Ikat Kepala. Permasalahan tersebut terjadi karena adanya tenaga kerja yang belum terampil dan cekatan pada proses penjahitan mesin. Berdasarkan pembebanan dari setiap tenaga kerja dibuat diagram gantt penjadwalan yang berguna untuk menunjukkan waktu dimulainya tugas untuk memproduksi sampai waktu pengerjaan tugas diselesaikan dan waktu prosesnya untuk mendapatkan gambaran penjadwalan yang lebih informatif.

\section{SIMPULAN}

Untuk mengatasi permasalahan keterlambatan waktu pada proses penjahitan, maka digunakan studi waktu agar dapat diketahui waktu standar dari proses penjahitan mesin. Dengan hasil studi waktu pada UKM songkok Ikat Kepala diketahui waktu standar untuk penjahitan ada 2, waktu standar cepat dan waktu standar lambat.Sehingga penjahitan mesin diketahui standar waktu cepat yaitu pengerjaannya cepat dihasilkan 444 detik dan standar waktu lambat yaitu pengerjaannya lama dapat dihasilkan 536 detik. 
Penjadwalan jangka pendek direncanakan pada diagram gantt yang menggambarkan tenaga kerja cepat yang menghasilkan 49 unit satu harinya, untuk 1 bulannya (26 hari) 1274 unit dan tenaga kerja yang lambat dapat menghasilkan 40 unit per hari, untuk perbulannya (26 hari) 1040 unit. Sedangkan normalnya setiap tenaga kerja diberi beban 45 unit per hari atau 1170 unit per bulan (26 hari). Sehingga tenaga kerja cepat dapat menyelesaikan 1170 unit dalam kurun waktu 24 hari dan 29 hari untuk tenaga kerja lambat.

\section{DAFTAR PUSTAKA}

Assauri, Sofjan. 2008. Manajemen Produksi dan Operasi Edisi Revisi.Penerbit Jakarta:LP FE UI

Heizer, Jay and Barry Render.2005. Manajemen Operasi edisi 7 buku 1. Jakarta: Salemba Empat.

Heizer, Jay and Barry Render. 2010. Manajemen Operasi. Jakarta: Salemba Empat.

Heizer, Jay and Barry Render.2015. Manajemen Operasi Manajemen Keberlangsungan dan Rantai Pasokan. Jakarta: Salemba Empat.

Kumar, Pardeep dan Mukesh Kumar. 2015. " Production Scheduling in a Job Shop Environment with consideration of Transportation Time and Shortest Processing
Time Dispatching Criterion" .IJAERA Vol.1 (2015).

Rahmawati, Noni Tri. 2015. Perencanaan pengukuran kerja dalam memtukan waktu standar dengan metode time study guna meningkatkan produktivitas kerja pada divisi pompa. Jurnal Ilmiah Manajemen Fakultas Ekonomi, Vol.1 (2015), hlm 1218.

Rinawati, Dyah Ika. 2012. "Penentuan waktu standar dan jumlah tenaga kerja optimal pada produksi batik cap ikm batik saud effendi,laweyan". J@TI UNDIP, Vol. 7 (2012).

Subhan, M. Thaib Hasan \& Suhendra. 2015 “ Peningkatan Produktivitas Kerja Dengan Metode Work Sampling pada Industri Batu Bata. Jurnal Ilmiah Fakultas Teknik, Universitas Samudra. JURUTERA vol.02 (2015), hlm 20-37.

Yusoff, Noriah. Ahmed Jaffar. Norliana Mohd Abbas \&Nor Hayati Saad. 2012. "Work Measurement For Process Improvement In The Car Seat Polyurethane Injection Manufacturing Line" Universitas Teknologi Mara Selangor. Procedia Engineering, Vol. 41 (2012), hlm: 1800-180. 